\title{
The evaluation of ovarian reserve and menstrual irregularities in female patients treated with systemic isotretinoin
}

\author{
Sistemik izotretinoin ile tedavi edilen kadın hastalarda over rezervinin ve menstrüel \\ düzensizliklerin değerlendirilmesi
}

\section{Pelin Kuteyla Can, ๑ Emek Kocatürk, ๑ Veli Mihmanlı*, ๑ Veysel Sucu**, ๑ Ece Nur Değirmentepe, ๑ Utkan Kızıltaç}

Prof. Dr. Cemil Tașcıoğlu City Hospital, Clinic of Dermatology; *Clinic of Obstetrics and Gynecology; ${ }^{* *}$ Clinic of Biochemistry, İstanbul, Turkey

\begin{abstract}
Background and Design: Isotretinoin is a widely used retinoid for the treatment of many dermatological conditions notably in acne with many known side effects. This study aims to investigate the effects of isotretinoin on anti-Mullerian hormone (AMH), follicle stimulating hormone (FSH) and total antral follicle count (TAFC) as the indicators of ovarian reserve (OR) and also aims to investigate the frequency of menstrual irregularities (MI).

Materials and Methods: Ninety-two reproductive women were included in this prospective controlled study. Study group is consisted of 32 healthy control, 29 low-dose $(0.4-0.6 \mathrm{mg} / \mathrm{kg} /$ day mean: 0.56 \pm 0.06$)$ and 31 high-dose isotretinoin received patients $(0.7-1.1 \mathrm{mg} / \mathrm{kg} / \mathrm{day} \mathrm{mean}$ $0.94 \pm 0.11)$. AMH, FSH and TAFC were evaluated before and at $6^{\text {th }}$ month of treatment in the treatment group, while AMH and FSH levels were evaluated in the control group.

Results: Mean AMH level of treatment group at the $6^{\text {th }}$ month of treatment was significantly lower than the level prior to treatment and that of the control group $(p<0.001, p=0.013)$. Mean FSH level was increased, and TAFC level was decreased compared to pretreatment period $(p=0,912, p=0,824)$. Seventeen patients $(28.3 \%)$ had Ml during treatment.

Conclusion: Although decrease in antral follicle numbers and increase in FSH levels were not significant, significant decreases in AMH levels may indicate the negative effect of isotretinoin on OR.
\end{abstract}

Keywords: AMH, isotretinoin, menstrual irregularities, ovarian reserve

\section{Öz}

Amaç: İotretinoin, başta akne olmak üzere birçok dermatolojik hastalığın tedavisinde sıkça kullanılan ve birçok yan etkisi bilinen bir retinoiddir. Bu çalışma, aknesi olan kadın hastalarda izotretinoinin over rezervinin (OR) göstergeleri olan anti-Müllerian hormon (AMH), folikül stimüle edici hormon (FSH) ve total antral folikül sayılarına (TAFS) etkisini ve menstrüel düzensizliklerinin (MD) sıklığını araştırmayı amaçlamaktadır. Gereç ve Yöntem: Prospektif kontrollü olan bu çalışmaya üreme çağındaki 92 kadın dahil edildi. Çalışma, 32 sağlıklı kontrol, 29 düşük doz

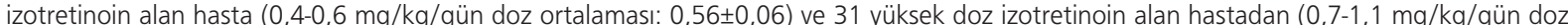
ortalaması: $0,94 \pm 0,11$ ) oluşmaktaydı. Tedavi grubunun serum AMH, FSH ve TAFS değerleri tedavi öncesi ve tedavinin altıncı ayı için, kontrol grubunun ise serum AMH ve FSH seviyeleri değerlendirilmiștir.

Bulgular: Tedavi grubunun tedavinin altıncı ayındaki ortalama serum AMH değerleri tedavi öncesinden ve kontrol grubundan istatistiksel olarak düşük bulunmuştur $(p<0,001, p=0,013)$. Ortalama serum FSH seviyelerinde artış ve TAFS seviyelerinde tedavi öncesine kıyasla düşüş saptanmıştır $(p=0,912, p=0,824)$. On yedi hastada $(\% 28,3)$ tedavi sırasında MD geliştiği saptandı.

Sonuç: Ortalama total antral folikül sayılarındaki düşüş ve folikül stimüle edici hormon seviyelerindeki artış anlamlı olmasa da, anti-Müllerian hormon seviyelerinde anlamlı düşüşler, izotretinoinin OR üzerine negatif etkisinin bir sonucu olduğunu destekler niteliktedir.

Anahtar Kelimeler: AMH, izotretinoin, menstrüel düzensizlik, over rezervi

Address for Correspondence/Yazışma Adresi: Pelin Kuteyla Can MD, Prof. Dr. Cemil Taşcıoğlu City Hospital, Clinic of Dermatology, İstanbul, Turkey Phone: +90 5356351538 E-mail: pulkumen@gmail.com Received/Geliş Tarihi: 13.09.2019 Accepted/Kabul Tarihi: 04.03.2020 ORCID: orcid.org/0000-0002-9124-5817 


\section{Introduction}

Isotretinoin (13-cis-retinoic acid) is a widely used retinoid for the treatment of many dermatological conditions notably in acne ${ }^{1}$. It has been approved by the Food and Drug Administration at 1982 for patients with severe recalcitrant nodulocystic acne and, it is the only molecule that acts on all four steps of the pathogenesis ${ }^{2,3}$. Isotretinoin is not only beneficial for dermatologic conditions, it is also used for many cancers and lymphomas by promoting differentiation ${ }^{4}$. It is a well-known and widely studied molecule with many side effects including mucocutaneous, rheumatologic, ophthalmic, gastrointestinal, neuromuscular, psychiatric, and laboratory abnormalities ${ }^{3,4}$. Besides it's well-known side effects, there are still unknown side effects and there is a lot of concern about isotretinoin's effect on fertility. There are only few stuides avaliable in the literature that investigate isotretinoin's effects on ovarian reserve $(O R)^{5-10}$.

Isotretinoin mainly acts on sebum suppression by sebocyte apoptosis which is induced by isotretinoin-induced expression of tumour necrosis factor-related apoptosis-inducing ligand, insulin-like growth factor binding protein-3 and neutrophil gelatinase-associated lipocalin ${ }^{11}$. Although apoptosis may participate at the main mechanism of action of the drug, it may also be the explanation for most of the adverse effects of isotretinoin, including impairment of OR.

This study aims to investigate isotretinoin's effects on anti-Mullerian hormone $(\mathrm{AMH})$, follicle stimulating hormone (FSH) and total antral follicle count (TAFC) as the indicators of OR by a different dose manner and also aims to investigate the frequency of menstrual irregularities $(\mathrm{MI})$ in isotretinoin treated female acne patients.

\section{Materials and Methods}

\section{Patient selection and data collection}

Ninety-two women in reproductive-age (15-34 years) were included in this prospective controlled parallel group study. This study was performed between September 2014 and October 2015. Study group consisted of 32 healthy controls, 29 acne patients under low-

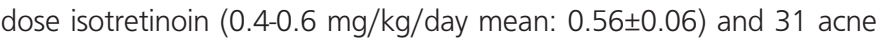
patients under high-dose isotretinoin $(0.7-1.1 \mathrm{mg} / \mathrm{kg} /$ day mean: $0.94 \pm 0.106)$. Patients with $\mathrm{Ml}$, polycystic ovary syndrome (PCOS), or any ovarian pathology (endometriosis or ovarian surgery), who had hormonal therapy, sistemic chemotherapy (CT), immunosupressants, antidepressants, steroids, mood stabilizers, alcohol, or retinoid treatment, patients with hormonal disregulation and patients on pregnancy or lactation were excluded from the study.

This study was approved by İstanbul Okmeydanı Training and Research Hospital Institutional Review Board and was conducted according to the Declaration of Helsinki (approval number: 135, date: 05.11.2013). Written informed consent was obtained from all participating patients.

Treatment design, evaluation of serum anti-Mullerian hormone, follicle stimulating hormone level, total antral follicle count and menstrual irregularities

Treatment group was divided as patients under low-dose isotretinoin ( $\mathrm{n}=29,0.4-0.6 \mathrm{mg} / \mathrm{kg} /$ day mean: $0.56 \pm 0.06)$ and patients under highdose isotretinoin ( $n=31,0.7-1.1 \mathrm{mg} / \mathrm{kg} /$ day mean: $0.94 \pm 0.106)$. The patients were monitorized monthly during isotretinoin treatment and all patients received oral isotretinoin for 6 months for acne. Treatment group's AMH, FSH and TAFC were evaluated before the treatment and at the $6^{\text {th }}$ month of treatment, while control group's AMH and FSH levels were evaluated once. Patients were also questioned if they had any $\mathrm{MI}$ before and during treatment.

Venous blood samples $(10 \mathrm{~mL})$ of the patients and the controls were obtained on days 2-5 of the menstrual cycle and samples were centrifuged for $15 \mathrm{~min}$ at $4,000 \mathrm{rpm}$ and then stored at $-80^{\circ} \mathrm{C}$. Serum $\mathrm{AMH}$ levels were analysed with enzyme-linked immunosorbent assay kit (Beckman Coulter, AMH Gen II ELISA A79765), serum FSH levels were analysed with automated electrochemiluminescence system [ROCHE Cobas 8000 (Germany) Elecsys]. All patients were evaluated with suprapubic pelvic ultrasonography (Xario, Toshiba Medical Systems, Japan, 3,5 to $5 \mathrm{mHz}$, convex probe) on the day $2-5^{\text {th }}$ of the mensturation to count the TAFC by a gynecologist who was blinded to all participants. TAFC was calculated by the sum of the number of antral follicles measuring 2-10 $\mathrm{mm}$ in diameter of the each ovaries. Normal menstrual cycle was defined as cycle intervals of 21-35 days and duration of bleeding of 4-7 days. Increased interval (delay) was termed if the menstrual cycle ran longer than 35 days, and decreased interval was termed if it ranless than 21 days. Abnormally low bleeding, less than $30 \mathrm{~mL}$ per menstrual cycle was termed as hypomenorrhea, excessive bleeding, over $90 \mathrm{~mL}$, in a cycle of normal duration was termed as hypermenorrhea.

\section{Statistical Analysis}

Statistical analyses were performed using the SPSS software version 22.0. All numerical variables were reported as the mean \pm standard deviation, median, frequency and percentages. The levels of significance values for differences in the mean AMH, FSH, TAFC following treatment approach were calculated Wilcoxon signed rank test. Mann-Whitney $U$ test was used to assess the differences in mean age, body mass index (BMI), AMH, FSH levels between the control and the treatment groups and it was also used to compare the differences in mean changes of the AMH, FSH levels and TAFC between the low and the high-dose groups and patients with $\mathrm{MI}$ and without MI. All analyses were performed by using non-parametric methods. Statistical significance was achieved at $p<0.05$ and $p<0.01$.

\section{Results}

Mean age of the control group $(25.91 \pm 3.95)$ was higher than the treatment group $(20.57 \pm 3.98)(p<0.001)$ but there was no significant difference between two treatment groups $(p=0.184)$. The mean BMI was statistically similar between control $(21.78 \pm 3.22)$ and treatment group (20.98 \pm 2.94$)(p=0.192)$.

The mean $\mathrm{AMH}$ level of the treatment group at month 6 was significantly lower than the level prior to treatment and that of the control group ( $p<0.001, p=0.013)$, although there was no significant difference between the mean $\mathrm{AMH}$ level of the treatment group and that of the control group prior to treatment $(p=0.967)$ (Table 1, Figure 1). Mean serum FSH level was found to be increased and TAFC were found to be decreased but these changes were not statistically significant ( $p=0,912, p=0,824)$ (Table 1). Mean AMH levels of both lowdose and high-dose groups were found significantly lower at month 6 than the levels before treatment $(p=0.005, p<0.001)$. When the $6^{\text {th }}$ month $\mathrm{AMH}$ levels of low and high-dose treatment groups were compared to controls, the mean $\mathrm{AMH}$ level was lower in the high- 
dose group than controls, while it was not significantly different in the low-dose treatment group than the control group $(p=0.009, p=0,097)$ (Table 1, Figure 1). Amount of changes in mean $\mathrm{AMH}, \mathrm{FSH}$ levels and TAFC of low-dose and high-dose groups were not significantly different between baseline and $6^{\text {th }}$ month $(p=0.395, p=0.663, p=0.584)$.

Seventeen of 60 patients (28,3\%) (10 under low-dose, 7 under highdose isotretinoin) had $\mathrm{Ml}$ during treatment (Figure 2). The onset of

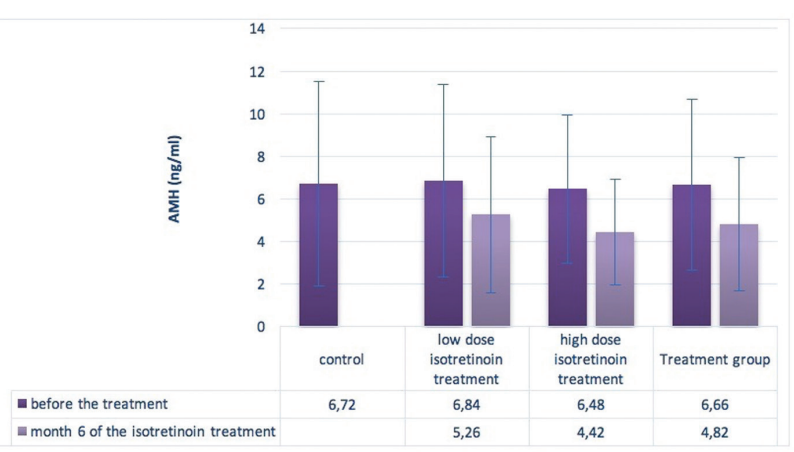

Figure 1. Mean serum anti-Mullerian hormone levels at baseline and at the end of isotretinoin treatment in the study and control groups AMH: Anti-Mullerian hormone the $\mathrm{MI}$ were mostly detected at $4^{\text {th }}$ month of the treatment and mean duration was $1.87 \pm 1.13$ months. While MI became normal during the treatment in most of the cases ( $n=11,64.7 \%)$, it became normal in 4 patients and continued in 2 patients after treatment cessation which were not linked to any gynecological pathology.

When AMH, FSH and TAFC were compared between the patients with and without any $\mathrm{Ml}$; $\mathrm{AMH}$ levels were found to be statistically higher

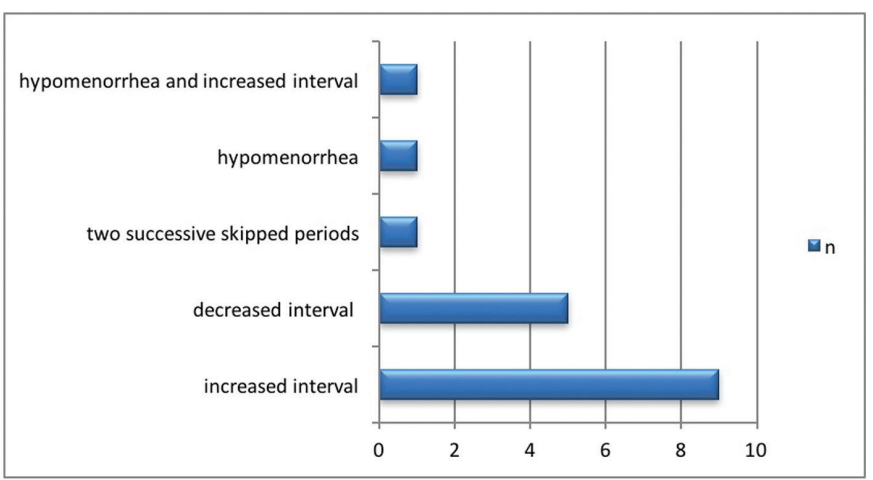

Figure 2. Number of the patients who developed menstrual irregularities during isotretinoin treatment

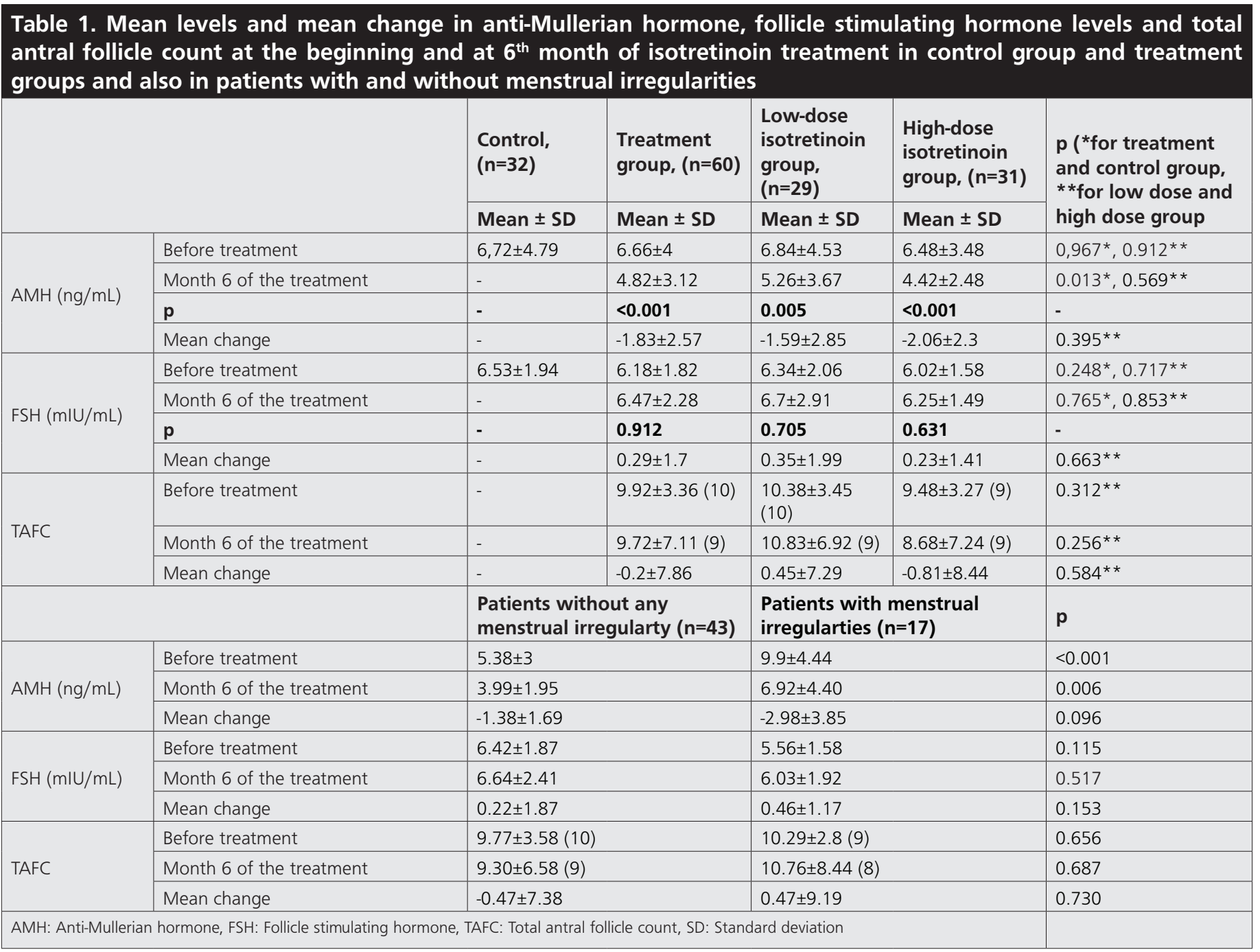


in the patients with $\mathrm{Ml}$ than patients without $\mathrm{Ml}$ at baseline and at $6^{\text {th }}$ month of treatment $(p<0.001, p=0.006)$, although the mean FSH and TAFC before the treatment and $6^{\text {th }}$ month of the treatment and mean change of all parameters between two groups were not statistically different ( $p>0.05)$ (Table 1).

\section{Discussion}

Several investigations evaluating the isotretinoin's effect on OR had been reported in the past five years and they show significant decreasing levels of $\mathrm{AMH}$ with isotretinoin treatment, and they also investigated isotretinoin's effects by evaluating other parameters including TAFC, ovarian volume (OV), FSH, luteinizing hormone (LH), estradiol (E2), testosterone (Table 2). In our study we showed that $\mathrm{AMH}$ level decreased significantly following the isotretinoin treatment which was also found to be significantly lower than that of the control group after the treatment. Although mean AMH levels at month 6 was found to be similar between the low dose treatment group and the control group, it was found to be significantly lower in the highdose treatment group than the control group. Mean change in $\mathrm{AMH}$ levels was not significantly different between high-dose and low-dose groups suggesting that the effect of isotretinoin on AMH levels is not dose related. TAFC and FSH level changes were insignificant but it may be due to the early testing of these parameters. There are also studies in the literature evaluating the isotretinoin's effect on pituitary hormones. One of them showed non-significant decreases in mean $\mathrm{FSH}, \mathrm{E} 2$, progesterone levels while LH and total testosterone decreased significantly ${ }^{12}$. The other study showed significant decreases in $\mathrm{LH}$ and total testosterone levels while non-significant decrease was observed in the mean $\mathrm{FSH}_{\text {level }}{ }^{13}$.

OR demonstrates the oocyte quality and the size of the primordial follicle pool accordingly indicates fertility ${ }^{14,15}$. AMH has been shown as a promising marker of the OR in many studies ${ }^{15,16}$. It is secreted by granulosa cells in early stages of follicle development (pre-antral and early antral follicles) ${ }^{15-18}$. It is the one of the earliest and most predictable marker for ovarian aging, while serum levels of FSH, Inhibin B, and E2 occur relatively late in the reproductive aging ${ }^{19,20}$. AMH has the best sensitivity and specificity compared to AFC, FSH, E2 and inhibin B levels or various ovarian challenge tests, but basal FSH, LH, inhibin $B$, or E2 are still in use for long term follow up after $\mathrm{CT}^{15,18}$. AMH shows more rapid and consistent changes in $\mathrm{CT}$ treated patients ${ }^{21}$ and it is also useful to evaluate the ovarian damage after surgery, and toxicity caused by ovarian toxic treatments, and radiation ${ }^{16,19}$.

The mechanism of action and adverse reactions may be associated with isotretinoin's effect on cell apoptosis ${ }^{11}$. The major mechanism of isotretinoin in patients with acne is sebum suppression. It promotes this action by sebocyte apoptosis ${ }^{22}$. Isotretinoin shows it's mechanism of action on acute promyelocytic leukaemia, and neuroblastoma by inducing apoptosis as well ${ }^{11}$. Isotretinoin is a prodrug which is isomerized to all-trans-retinoic acid that induces apoptosis in sebaceous glands, meibomian glands, neuroblastoma cells, hypothalamic cells, and other. Therapeutic, adverse, teratogenic and chemopreventive effecs of isotretinoin are all mediated by upregulation of Forkhead box O (FoxO) mediated gene transcription ${ }^{23}$. Shen et al. ${ }^{24}$ had reported FoxO1 expression in mouse granulosa cell apoptosis induced by oxidative stress. FoxO-mediated granulosa cell apoptosis may be the explanation of $\mathrm{AMH}$ decrease after isotretinoin treatment.

Abali et al. ${ }^{9}$ had first investigated the effects of isotretinoin on OR in female Sprague-Dawley rats. AMH levels were significantly lower in the treatment group than control group independent from the dose. Lower number of proliferating cell nuclear antigen positive granulosa cells and higher TUNEL-positive granulosa cells were observed in the isotretinoin treated groups. The study showed that percentage of atretic follicles and number of ovarian follicles containing apoptotic granulosa cells was higher in the experimental groups.

Two recent investigations showed that isotretinoin's effect on OR can be reversible ${ }^{5,6}$. In one of these investigations which was performed on rats it was shown that there were no statistically significant differences in the $\mathrm{AMH}$ values one month after treatment cessation compared to pretreatment values, although there was a significant decrease after the treatment ${ }^{6}$. In the other study, all parameters associated with the OR were evaluated and mean AMH, OV and TAFC values at the beginning and 12 months after the treatment cessation were found to be statistically similar although these three parameters decreased significantly just after the treatment ${ }^{5}$. These two studies showed that mean $\mathrm{AMH}$ concentrations increased after isotretinoin cessation, and they support that the effect of isotretinoin on ORs might be reversible but the mechanism of increase in AMH levels is controversial. AMH is also used as a predictor of OR in cancer patients and there are also reports showing the $\mathrm{OR}$ recovery after $\mathrm{CT}$ had been stopped ${ }^{25,26}$. AMH levels decreased just after the beginning of $\mathrm{CT}$ due to destruction of ovarian follicles and increased follicular atresia, but recovery in $\mathrm{AMH}$ after CT was reported and it may be associated with reinitiation of follicle growth, the restoration of the small growing follicle pool, which in turn reflects the size on the non-growing, primordial pool ${ }^{26,27}$ The primordial follicle pool is less damaged when the non-alkylating protocols used so they allow the rapid emergence of newly growing and $\mathrm{AMH}$-secreting follicles although absence of a recovery in high-risk treatment groups may be caused by a profound loss of the primordial follicle pool unable to generate sufficient small growing follicles to secrete $A M H^{25,27}$. The same mechanism may be an explanation of the isotretinoin's reversible effect on OR.

There are several reports of $\mathrm{Ml}$ due to isotretinoin treatment ${ }^{28-32}$. Kwon et al. ${ }^{29}$ reported that $20 \%(n=8)$ of the patients had Ml during the isotretinoin treatment. Skipped periods in 4 patients, increased interval in two patients, decreased interval and amount in a patient, and intermenstrual bleeding in a patient were reported. Menstruation periods returned to normal after isotretinoin cessation. In another study evaluating the side effects of isotretinoin releaved that $18.6 \%(n=28)$ of the patients developed $\mathrm{Ml}$ ( $2^{\text {nd }}$ or $3^{\text {rd }}$ month). While mensturation periods returned to normal in most of the cases $(n=22)$ during the treatment ${ }^{33}$. Tükenmez Demirci et al. ${ }^{32}$ reported $28.8 \%(n=16)$ of the patients had developed $\mathrm{Ml}$; 6 of these patients with prolong interval, 4 with hypomenorhea, 2 with prolonged interval and hypomenorhea, 2 with metrorrhagia, one with shortened interval and one with missed period. In our study group, $28.3 \%$ patients $(n=17)$ had Ml during treatment which presented mostly as increased interval. MI became normal during the treatment in most of the cases $(n=11,64.7 \%)$ which also supports the idea that isotretinoin effects on ovaries are reversible. In our study, $\mathrm{AMH}$ levels of patients with $\mathrm{MI}$ was higher than that of patients without MI. However no significant difference was observed with regard to mean change of the $\mathrm{AMH}$ levels between the patients with $\mathrm{Ml}$ and patients without MI. High levels of $\mathrm{AMH}$ may be an indicator of PCOS but all patients were assesed before and the $6^{\text {th }}$ month of therapy for any gynecologic pathology; none of them had $\mathrm{PCOS}^{34}$. We may suggest that, these patients might have a tendency to 


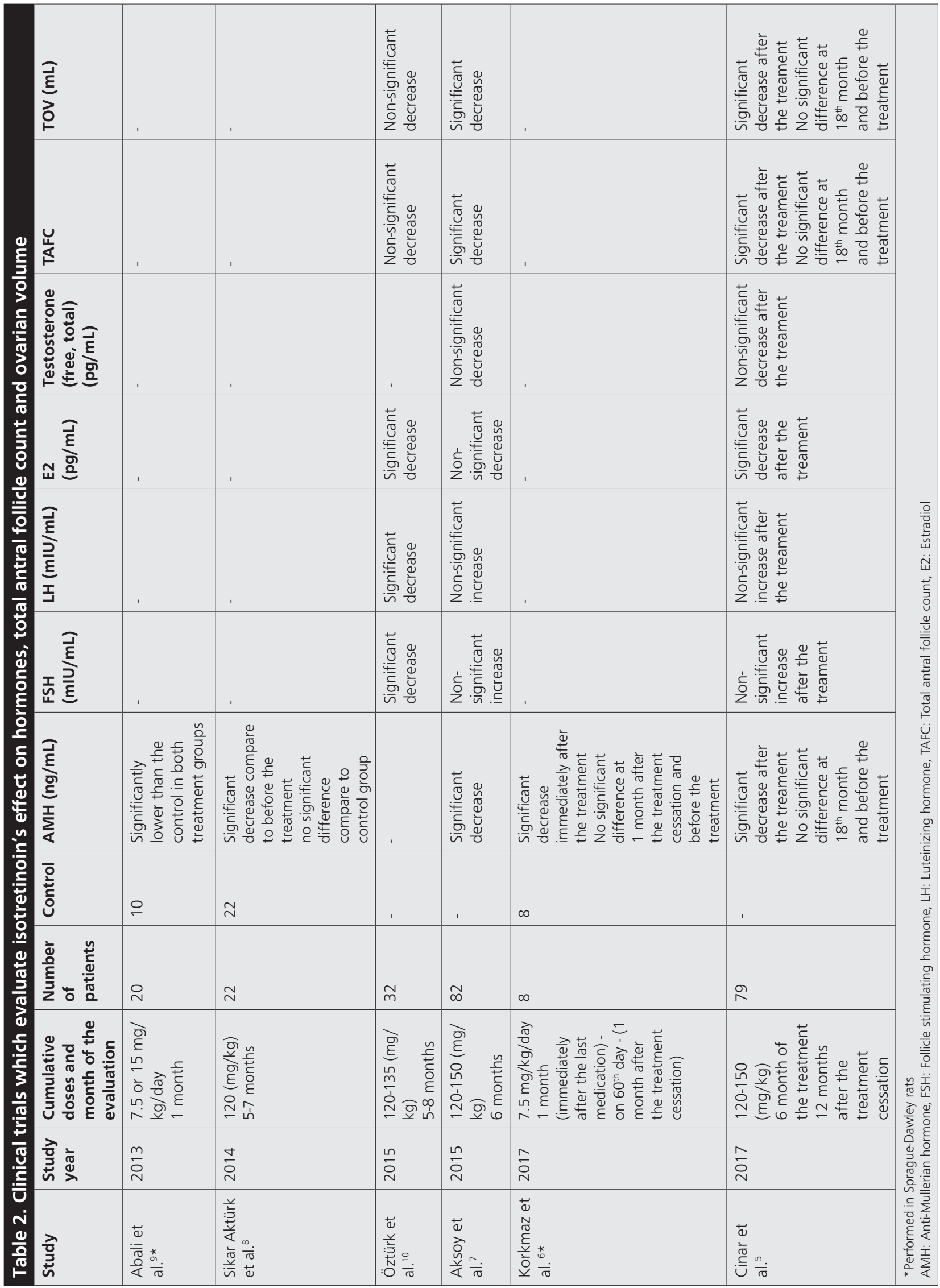


have PCOS and isotretinoin treatment might have triggered PCOS-like symptoms in those patients who have high $\mathrm{AMH}$ levels at baseline. But this observation needs further approval with accordingly designed studies which evaluate $\mathrm{AMH}$ levels at the time interval when MI starts.

\section{Study Limitation}

Our limitation in this study was that we did not evaluate the AMH levels after a rationale time passed from the treatment cessation.

\section{Conclusion}

Isotretinoin is a frequently prescribed drug for patients with acne with well known side effects. Fertility is the major concern of the patients and parents of young adults. Albeit the decrease in $\mathrm{AMH}$ level is significant, this effect may be reversible. Studies evaluating $\mathrm{AMH}$ levels after a rationale time passed from the treatment cessation are needed. The pathogenesis of $\mathrm{Ml}$ remains to be determined.

\section{Ethics}

Ethics Committee Approval: This study was approved by i̇stanbul Okmeydanı Training and Research Hospital Institutional Review Board and was conducted according to the Declaration of Helsinki (approval number: 135, date: 05.11.2013).

Informed Consent: Written informed consent was obtained from all participating patients.

Peer-review: Externally peer-reviewed.

\section{Authorship Contributions}

Surgical and Medical Practices: E.K., P.K.C., V.M., V.S., Concept: E.K., P.K.C., V.M., V.S., Design: E.K., P.K.C., V.M., V.S., Data Collection or Processing: E.K., P.K.C., V.M., V.S., E.N.D., U.K., Analysis or Interpretation: E.K., P.K.C., V.M., V.S., E.N.D., U.K., Literature Search: E.K., P.K.C., V.M., V.S., E.N.D., Writing: E.K., P.K.C., V.S., E.N.D.

Conflict of Interest: Dr. Emek Kocatürk reports advisory board fees from Novartis, and has served as a medical advisor for Bayer. The other authors have no conflict of interest to declare.

Financial Disclosure: This work was supported by Turkish Society of Dermatology under Grant.

\section{References}

1. Forbat $E$, Ali FR, Al-Niaimi F: Dermatological indications for the use of isotretinoin beyond acne. J Dermatolog Treat 2018;29:698-705.

2. Leyden JJ, Del Rosso JQ, Baum EW: The use of isotretinoin in the treatment of acne vulgaris: clinical considerations and future directions. J Clin Aesthet Dermatol 2014;7:(2 Suppl):S3-S21.

3. Khalil S, Bardawil T, Stephan C, et al: Retinoids: A journey from the molecular structures and mechanisms of action to clinical uses in dermatology and adverse effects. J Dermatolog Treat 2017;28:684-96.

4. Ellis $\mathrm{CN}$, Krach KJ: Uses and complications of isotretinoin therapy. J Am Acad Dermatol 2001:45:150-7.

5. Cinar SL, Kartal D, Aksoy H, et al: Long-term effect of systemic isotretinoin on female fertility. Cutan Ocul Toxicol 2017;36:132-4.

6. Korkmaz E, Cetinkaya $\mathrm{N}, \mathrm{Oz} \mathrm{M}$, et al: The possibly reversible isotretinoin effect of decreased ovarian reserve in sprague-dawley albinos: Part I, biochemical analyses. Gynecol Obstet Invest 2017;82:72-7

7. Aksoy $H$, Cinar $L, A c m a z ~ G$, et al: The effect of isotretinoin on ovarian reserve based on hormonal parameters, ovarian volume, and antral follicle count in women with acne. Gynecol Obstet Invest 2015;79:78-82.

8. Sikar Aktürk A, Abalı R, Yüksel MA, Çelik Güzel E, Güzel S, Kıran R: The effects of isotretinoin on the ovarian reserve of females with acne. Gynecol Endocrinol 2014;30:30-3

9. Abali R, Yuksel MA, Aktas C, et al: Decreased ovarian reserve in female Sprague-
Dawley rats induced by isotretinoin (retinoic acid) exposure. Reprod Biomed Online 2013;27:184-91.

10. Öztürk S, Öztürk T, Ucak H, et al: Evaluation of ovarian reserve and function in female patients treated with oral isotretinoin for severe acne: an exploratory study. Cutan Ocul Toxicol 2015;34:21-4.

11. Melnik BC: Apoptosis May Explain the Pharmacological Mode of Action and Adverse Effects of Isotretinoin, Including Teratogenicity. Acta Derm Venereol 2017;97:173-81.

12. Karadag AS, Ertugrul DT, Tutal E, Akin KO: Isotretinoin influences pituitary hormone levels in acne patients. Acta Derm Venereol 2011;91:31-4.

13. Karadag AS, Takci Z, Ertugrul DT, Bilgili SG, Balahoroglu R, Takir M: The effect of different doses of isotretinoin on pituitary hormones. Dermatology 2015;230:354-9.

14. Gruijters MJG, Visser JA, Durlinger AL, Themmen AP: Anti-müllerian hormone and its role in ovarian function. Mol Cell Endocrinol 2003;211:85-90.

15. Kunt $C$, Ozaksit $G$, Keskin Kurt $R$, et al: Anti-Mullerian hormone is a better marker than inhibin B, follicle stimulating hormone, estradiol or antral follicle count in predicting the outcome of in vitro fertilization. Arch Gynecol Obstet 2011;283:1415 21.

16. Iwase A, Nakamura T, Nakahara T, Goto M, Kikkawa F: Anti-Müllerian hormone and assessment of ovarian reserve after ovarian toxic treatment: a systematic narrative review. Reprod Sci 2015;22:519-26.

17. Kruszyńska A, Słowińska-Srzednicka J: Anti-Müllerian hormone (AMH) as a good predictor of time of menopaus. Prz Menopauzalny 2017;16:47-50.

18. Broer SL, Broekmans FJ, Laven JS, Fauser BC: Anti-Müllerian hormone: ovarian reserve testing and its potential clinical implications. Hum Reprod Update 2014;20:688-701.

19. Iwase A, Osuka S, Nakamura T, et al: Usefulness of the Ultrasensitive Anti-Müllerian Hormone Assay for Predicting True Ovarian Reserve. Reprod Sci 2016;23:756-60.

20. Singh N, Malik E, Banerjee A, Chosdol K, Sreenivas V, Mittal S: "Anti-Mullerian Hormone: Marker for Ovarian Response in Controlled Ovarian Stimulation for IVF Patients": A First Pilot Study in the Indian Population. J Obstet Gynaecol India 2013;63:268-72.

21. Fréour $T$, Barrière $P$, Masson D: Anti-müllerian hormone levels and evolution in women of reproductive age with breast cancer treated with chemotherapy. Eur J Cancer 2017:74:1-8.

22. Nelson AM, Gilliland KL, Cong Z, Thiboutot DM: 13-cis Retinoic acid induces apoptosis and cell cycle arrest in human SEB-1 sebocytes. J Invest Dermatol 2006;126:2178-89.

23. Melnik BC: Isotretinoin and FoxO1: A scientific hypothesis. Dermatoendocrinol 2011;3:141-65

24. Shen M, Lin F, Zhang J, Tang Y, Chen WK, Liu H: Involvement of the up-regulated FoxO1 expression in follicular granulosa cell apoptosis induced by oxidative stress. J Biol Chem 2012;287:25727-40.

25. Peigné $M$, Decanter $C$ : Serum AMH level as a marker of acute and long-term effects of chemotherapy on the ovarian follicular content: a systematic review. Reprod Biol Endocrinol 2014;12:26.

26. Dillon $\mathrm{KE}$, Sammel MD, Prewitt $M$, et al: Pretreatment antimüllerian hormone levels determine rate of posttherapy ovarian reserve recovery: acute changes in ovarian reserve during and after chemotherapy. Fertil Steril 2013;99:477-83.

27. Brougham MF, Crofton PM, Johnson EJ, Evans N, Anderson RA, Wallace WH: AntiMüllerian hormone is a marker of gonadotoxicity in pre- and postpubertal girls treated for cancer: a prospective study. J Clin Endocrinol Metab 2012;97:2059-67.

28. Christmas T: Roaccutane and menorrhagia. J Am Acad Dermatol. 1988;18:576-7.

29. Kwon HJ, Lee JY, Cho BK, Park HJ: Menstrual irregularity during isotretinoin treatment. J Eur Acad Dermatol Venereol 2007;21:562-3.

30. Cox NH: Amenorrhoea during treatment with isotretinoin. $\mathrm{Br} J$ Dermatol 1988;118:857-8.

31. McElwee NE, Schumacher MC, Johnson SC et al: An observational study of isotretinoin recipients treated for acne in a health maintenance organization. Arch Dermatol 1991;127:341-6.

32. Tükenmez Demirci G, Mertoğlu E, Kıvanç Altunay I, Atış G, Küçükünal A: The investigation of the frequency of menstrual irregularity and hypertrichosis due to isotretinoine usage in female patients. Turkderm 2014;48:152-5.

33. Karadağ AS, Calka O, Akdeniz N: Evaluation of Side Effects of Isotretinoin in 150 Patients with Acne Vulgaris. Turkderm 2011;45:37-42.

34. Casadei L, Fanisio F, Sorge RP, Collamarini M, Piccolo E, Piccione E: The diagnosis of PCOS in young infertile women according to different diagnostic criteria: the role of serum anti-Müllerian hormone. Arch Gynecol Obstet 2018;298:207-15. 